\title{
A Comparison between the Rate of Reaction of Nitric Oxide in the Gas Phase and in Whole Cigarette Smoke*
}

by

\author{
C. D. R. Borland, A. T. Chamberlain and T. W. Higenbottam \\ Department of Respiratory Physiology, Addenbrooke's Hospital, Cambridge, England
}

R. W. Barber

Department of Nuclear Medicine, Addenbrooke's Hospital, Cambridge, England

and

\section{B. A. Thrusb}

Department of Physical Chemistry, University of Cambridge Chemical Laboratory, Cambridge, England

\section{SUMMARY}

There remains uncertainty about the rate of oxidation of nitric oxide (NO) in cigarette smoke. Using a singleport smoking machine and a chemiluminescence NO analyser we have investigated the rate of NO disappearance during cigarette smoke ageing over 10 minutes for gas phase and whole smoke.

The disappearance of NO in whole smoke conformed to the (pseudo) second order kinetics observed for oxidation of NO in air. In the gas phase however the rate of disappearance was more rapid and appeared to follow first order kinetics. The possible mechanisms for this difference in behaviour are discussed.

\section{ZUSAMMENFASSUNG}

Die Oxidationsgeschwindigkeit von Stickoxid (NO) in Zigarettenrauch ist weiterhin unklar. Unter Verwendung einer Einkanal-Rauchmaschine und eines NOChemolumineszenz-Analysators wurde die Geschwindigkeit der NO-Abnahme während der Alterung von Zigarettenrauch in der Gasphase und im Gesamtrauch

* Received: 26th July 1984 - accepted: 7th March 1985. über einen Zeitraum von zehn Minuten untersucht.

Die Abnahme von NO im Gesamtrauch stimmte mit der bei der Oxidation von NO in Luft zu beobachtenden Kinetik (pseudo)zweiter Ordnung überein. Die Schwundrate in der Gasphase war jedoch größer und schien einer Kinetik erster Ordnung zu entsprechen. Die diesem unterschiedlichen Verhalten möglicherweise zugrundeliegenden Mechanismen werden diskutiert.

\section{RESUME}

Il règne encore une certaine incertitude quant à la vitesse d'oxydation de l'oxyde d'azote (NO) dans la fumée de cigarette. On a utilisé une machine à fumer à un seul canal avec analyseur de NO par chimiluminescence pour étudier la vitesse de disparition de ce gaz pendant 10 minutes de vieillissement de la fumée, tant pour la phase gazeuse que pour la fumée totale.

Le processus de disparition du NO dans la fumée totale est bien décrit par le modèle cinétique différentiel du (pseudo) second ordre, correspondant à l'oxydation du NO dans l'air. Cependant la vitesse de disparition dans la phase gazeuse est plus rapide et semble suivre un modèle cinétique différentiel du premier ordre. Les mécanismes possibles pour expliquer ces différences de comportement sont discutés. 
Figure 1.

Agolng in gas phase.

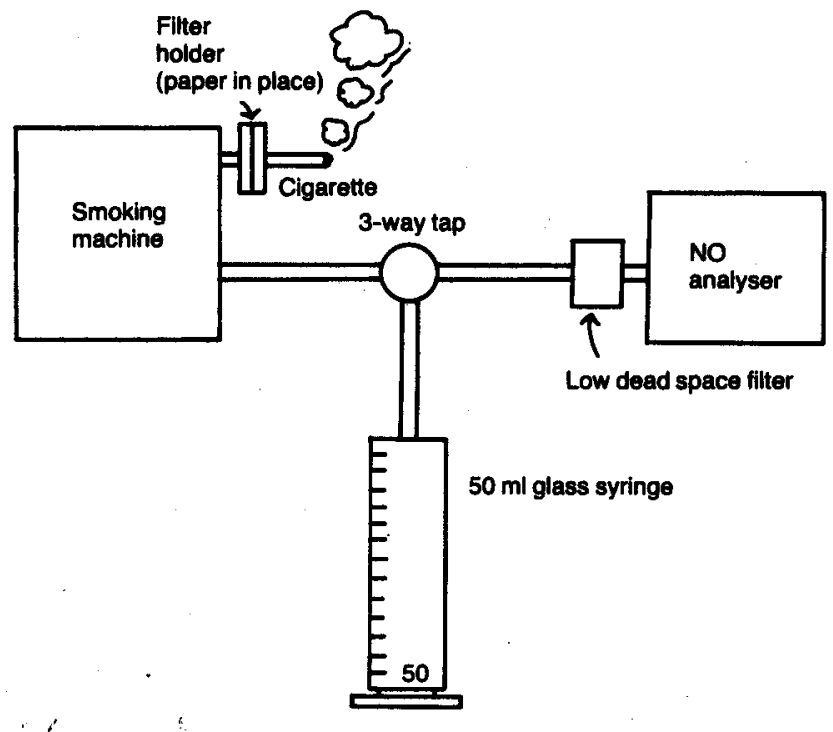

Figure 2.

Ageing in whole smoke.

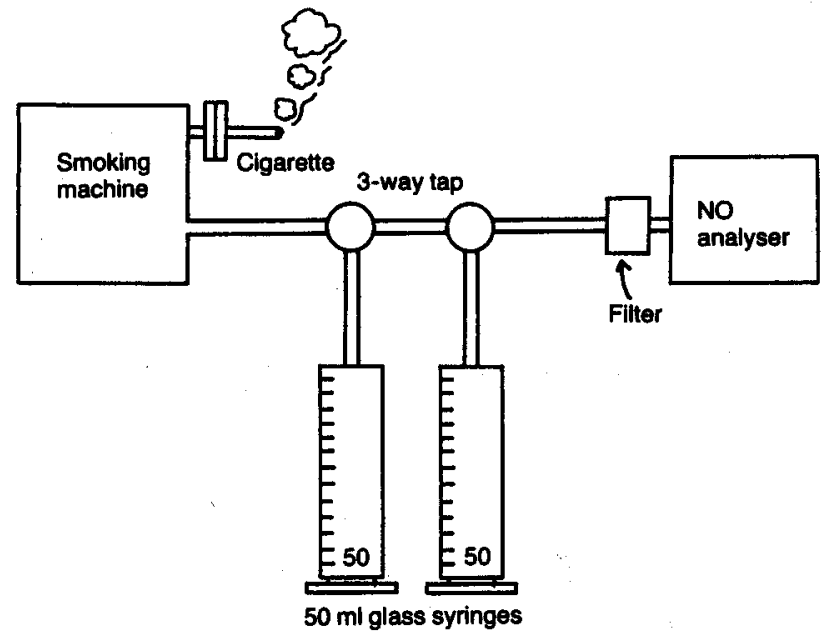




\section{INTRODUCTION}

Fresh cigarette smoke contains up to 1000 parts per million (ppm) of nitric oxide (NO) per puff (1). This yield is largely dependent on the nitrate content of the tobacco used in manufacture (2) and hence is higher for "U.S. blended" and "dark air-cured" varieties than for cigarettes manufactured from "Bright (Virginia)" or "Oriental" tobacco (3). On ageing the smoke NO is initially oxidised to nitrogen dioxide $\left(\mathrm{NO}_{2}\right)(4)$ and subsequently reacts to form methyl nitrite (5). The reaction of $\mathrm{NO}$ with oxygen to yield $\mathrm{NO}_{2}$ is known to be third order:

$$
-\frac{\mathrm{d}[\mathrm{NO}]}{\mathrm{dt}}=2 \mathrm{k}\left[\mathrm{NO}^{2}\left[\mathrm{O}_{2}\right]\right. \text {. }
$$

The recommended value for $k$ derived from an extensive review of experimental values is

$$
1.2 \times 10^{9} \exp \left(530 / \mathrm{T}^{*}\right) \mathrm{cm}^{6} \mathrm{~mol}^{-2} \mathrm{~s}^{-1}(6) \text {. }
$$

There is a disagreement' among previous investigators regarding the value of $\mathrm{k}$ for the oxidation of $\mathrm{NO}$ in cigarette smoke. Sloan and $\mathrm{Kiefer}(2)$ found a similar value to that recommended (6) whilst Williams (7) obtained a rather higher figure. We have investigated the rate and order of this reaction in undiluted whole smoke and in gas phase and present a possible mechanism for the different kinetics observed which may explain the different rate constants found by earlier workers.

\section{EXPERIMENTAL}

\section{Cigarettes}

A popular U.K. king-size $(85 \mathrm{~mm}$ ) (all flue-cured) middle tar $(18 \mathrm{mg}$ ) filter cigarette was used. Packets were purchased retail, opened and stored in an airtight container at constant humidity over a saturated sodium bromide solution for at least $\mathbf{4 8}$ hours prior to smoking (8). Previous determinations we have made for this brand gave a mean yield of 135 micrograms $(\mu \mathrm{g}) \mathrm{NO}$ which is at the top end of the range for current U.K. cigarettes.

\section{Smoking Machine}

A standard single-port restricted smoking machine was used (Heinrich Borgwaldt, Hamburg: RM 1/G-R58). A single cigarette was inserted in the filter holder, lit and smoked in the standard fashion, i.e. $35 \mathrm{ml}$ bell-shaped puff of 2-second duration taken once per minute (8). The third puff, empirically found to have the most reproducible concentration of nitric oxide, was then di-

\footnotetext{
* absolute temperature (kelvin).
}

rected into a $50 \mathrm{ml}$ glass syringe where ageing occurred for 0 to 10 minutes. The cigarette was then extinguished. Following ageing the concentration of nitric oxide remaining in the syringe was measured. For determinations of the reaction rate in the gas phase, a $35 \mathrm{~mm}$ Cambridge filter ( $\mathrm{T} 39 \mathrm{Z}^{* *}$ ) was inserted into the filter holder on the smoking machine. For determination on the whole smoke the filter was omitted, but the machine was regularly cleaned to remove deposited tar; in addition the exhaust from the machine was directed into a second $50 \mathrm{ml}$ syringe since in practice it was found that tar deposited on the inside of the barrel of the syringe prevented aspiration of the sample into the analyser. This syringe was normally emptied into the first immediately prior to analysis. For both gas phase and whole smoke the 3-way tap was turned to permit aspiration of the sample once the ageing period had elapsed (see Figs. 1 and 2).

\section{Nitric Oxide Analysis}

Nitric oxide was analysed by a purpose-built instrument ${ }^{* \star \star}$ for estimation of NO in the gas phase of tobacco smoke. The sample was aspirated at a rate of $120 \mathrm{ml} / \mathrm{min}$ and exposed to ozone generated from oxygen within the device by $\mathrm{EHT}^{+}$discharge. Some $\mathrm{NO}_{2}$ is formed in an excited state and emits photons of light in the near infra-red which are detected by a photomultiplier (9). The resulting signal is amplified and conditioned and plotted on a pen recorder (Vitatron $2001^{++}$). To prevent any deposition of particulate matter within the analyser the sample was passed through a Cambridge filter in a low dead space holder prior to sampling (see Figs. 1 and 2).

\section{Number of Analyses}

Two replicates were made for both gas phase and whole smoke for ageing periods of 0 to 10 minutes in 1-minute intervals. The order of ageing interval was randomised.

\section{Oxygen Analysis}

In a separate experiment the oxygen concentration for the third puff of the same brand of cigarette smoked in an identical fashion was determined. Oxygen analysis was performed by mass spectrometer (MGA 200 $0^{++}$) calibrated for oxygen in air and in a mixture of oxygen $(14 \%)$, argon $(8 \%)$, carbon dioxide $(8 \%)$, the remainder nitrogen. A sample was aspirated directly from the syringe via a filter and 5 replicates were performed for

\footnotetext{
** Evans Adlard \& Co. Led., Winchcombe, CheJcenham, Glos., England

*** Cheml_ab Instruments Itd, Hornchurch, Essex, England.

+ electrical high tension.

t+ Fisons Scientific Apparatus, Loughborough, Leics, England

+t+ Centronic Led., Croydon, Surrey, England.
} 
Flgure 3.

1/[NO] vs. tlme for varyling agelng perlods. (Predicted slope using $\mathrm{k}=7.3 \times 10^{9} \mathrm{~cm}^{8} \mathrm{~mol}^{-2} \mathrm{~s}^{-1}$ and $\mathrm{O}_{2}$ concentration of $14.4 \%$ (Tables 1 and 2).)

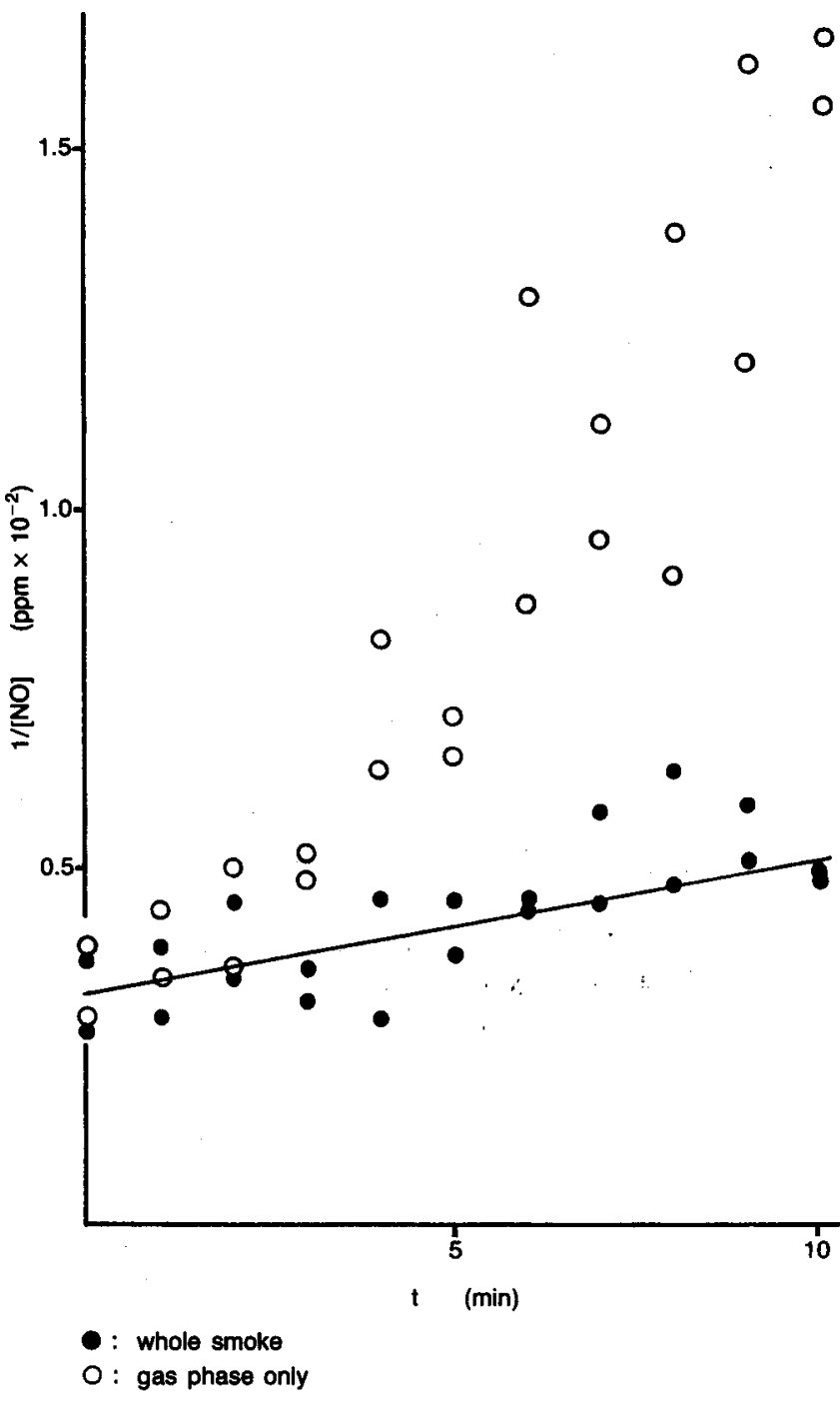

whole smoke and separated gas phase immediately after taking the puff and after a 10-minute ageing period.

\section{RESULTS}

The rate of oxidation of nitric oxide is third order and when oxygen is greatly in excess it will become (pseudo) second order (2):

$$
-\frac{\mathrm{d}[\mathrm{NO}]}{\mathrm{dt}}=2 \mathrm{k}\left[\mathrm{O}_{2}\right][\mathrm{NO}]^{2} \text {. }
$$

The integration and rearrangement of the above reaction equation results in:

$$
\frac{1}{[\mathrm{NO}]_{\mathfrak{t}}}=2 \mathrm{k}\left[\mathrm{O}_{2}\right] \mathrm{t}+\frac{1}{[\mathrm{NO}]_{0}},
$$

where $[\mathrm{NO}]_{0}$ is concentration at time 0 and $[\mathrm{NO}]_{t}$ after
Figure 4.

Nitric oxide concentration (log vs. time). Line represents least mean squares regression slope.

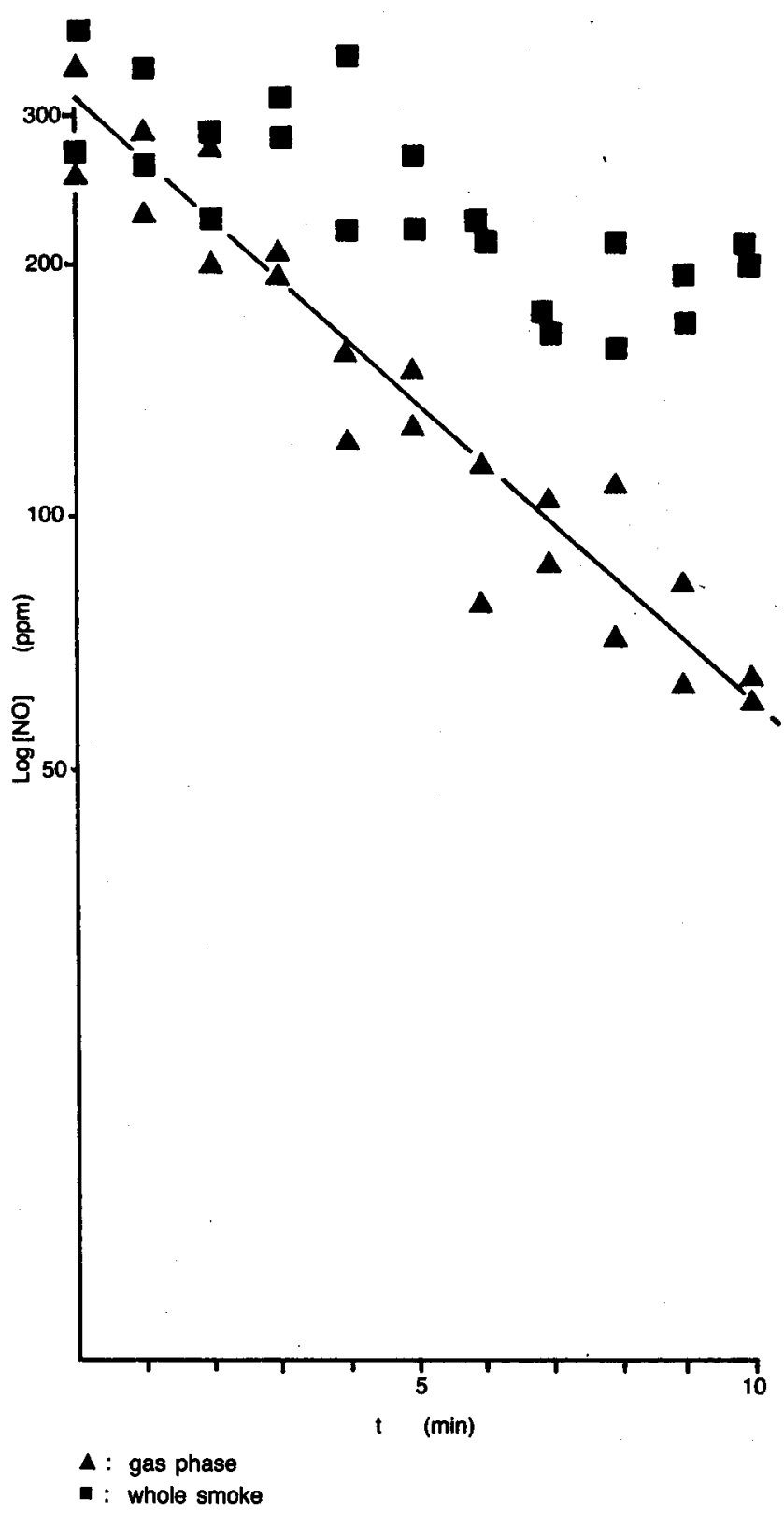

interval $t$. Thus a graph of $1 /[\mathrm{NO}]$ vs. $t$ should be linear with slope $2 \mathrm{k}\left[\mathrm{O}_{2}\right]$, and if $\left[\mathrm{O}_{2}\right]$ is known $\mathrm{k}$ may be determined (2).

\section{Disappearance from Whole Smoke}

Figure 3 shows that for ageing in whole smoke the disappearance of NO closely conforms to the predicted slope given the initial NO concentrations using the recommended rate constant of $7.3 \times 10^{9} \mathrm{~cm}^{6} \mathrm{~mol}^{-2} \mathrm{~s}^{-1}$ for the mean temperature of $293 \mathrm{~K}$ and barometric pressure of $767 \mathrm{~mm} \mathrm{Hg}$ recorded during these experiments and using the mean oxygen concentration of $14.4 \%$ measured. 
Table 1.

Concentration (\%) of oxygen In puff [mean (standard deviation)

of 5 estimations on each phase and time interval].

\begin{tabular}{|c|c|c|c|c|}
\hline & \multicolumn{4}{|c|}{ Time (minutes) } \\
\hline & \multicolumn{2}{|c|}{0} & \multicolumn{2}{|c|}{10} \\
\hline Whole smoke & 14.2 & $(0.9)$ & 14.5 & $(0.6)$ \\
\hline Gas phase & 14.6 & $(0.3)$ & 14.1 & (0.3) \\
\hline
\end{tabular}

Table 2. Values for rate constants.

\begin{tabular}{|c|c|c|c|c|c|c|}
\hline \multicolumn{6}{|c|}{ 1. Rate constant $k$ for third order reàction $-\frac{d[\mathrm{NO}]}{d t}=2 \mathrm{k}[\mathrm{NO}]^{2}\left[\mathrm{O}_{2}\right]$} & \multirow[t]{2}{*}{ Source } \\
\hline \multicolumn{3}{|c|}{$[\mathrm{k}]=\mathrm{cm}^{6} \mathrm{~mol}^{-2} \mathrm{~s}^{-1}$} & \multicolumn{3}{|c|}{$[k]=1^{2} \mathrm{~mol}^{-2} \mathrm{~min}^{-1}$} & \\
\hline 8.6 & $x$ & $10^{9}$ & 5.2 & $x$ & $10^{8}$ & our data (whole smoke) \\
\hline 8.0 & $x$ & $10^{\circ}$ & 4.8 & $x$ & $10^{5}$ & unspecified phase (2) \\
\hline 7.3 & $x$ & $10^{9}$ & 4.4 & $x$ & $10^{5}$ & recommended at $22{ }^{\circ} \mathrm{C}(6)$ \\
\hline 4.3 & $x$ & $10^{10}$ & 2.6 & $x$ & $10^{8}$ & our data (gas phase) \\
\hline $\begin{array}{l}0.83 \\
\text { to } \\
2.8\end{array}$ & $\times$ & $10^{10}$ & $\begin{array}{l}0.50 \\
\text { to } \\
1.65\end{array}$ & $x$ & $10^{8}$ & gas phase (7) \\
\hline \multicolumn{6}{|c|}{ 2. Rate constant $k$ for first order reaction $-\frac{d[\mathrm{NO}]}{d t}=k[\mathrm{NO}]$} & \multirow{4}{*}{$\begin{array}{l}\text { our data (gas phase) } \\
\text { estimated from gas phase (5) }\end{array}$} \\
\hline \multicolumn{6}{|c|}{$[k]=s^{-1}$} & \\
\hline \multicolumn{6}{|c|}{$2.7 \times 10^{-3}$} & \\
\hline \multicolumn{6}{|c|}{$7.0 \times 10^{-3}$} & \\
\hline
\end{tabular}

\section{Disappearance from Isolated Gas Phase}

Disappearance of NO from the gas phase proceeds considerably faster than either the predicted slope or that observed for the whole smoke. In comparison, Figure 4 shows that the disappearance from gas phase is best fitted by a logarithmic decay curve, i.e. first order kinetics giving a rate constant of $2.7 \times 10^{-3} \mathrm{~s}^{-1}$.

\section{Experimentally Determined Rate Constants}

Table 1 shows the experimentally determined oxygen concentrations for the third puff. Table 2 shows the rate constants derived for whole smoke and gas phase assuming (pseudo) second order kinetics together with values obtained by earlier observers $(2,7)$. The close agreement between our value for whole smoke, that of Sloan and Kiefer (2) and the recommended value (6) is apparent. On the other hand our value for gas phase agrees with that of Williams (7). In addition, if we as- sume first order kinetics, the rate constant we have derived for gas phase agrees reasonably well with that we have estimated from Vilcins and Lephardt (5) if the absorbance decay for NO in their figure is plotted against time on a semilog graph.

\section{DISCUSSION}

Our results and those of others who have studied the disappearance of $\mathrm{NO}$ in the isolated gas phase $(5,7)$ suggest that the oxidation proceeds faster than predicted. It would seem unlikely that the increased loss we observed could be due to leakage or apparatus dead space because of the similarity of our experimental system for each phase. Similarly the filter on the entry port of the analyser should prevent particulates causing a falsely elevated signal when whole smoke was analysed. The similarity of the $t=0$ values for NO for gas phase and for whole smoke provides further evidence against this possibility. 
The results also show clearly that the oxidation of NO in the gas phase is faster than in whole smoke. We do not believe that this phenomenon is confined to fluecured Virginia cigarettes since similar results (see $\mathrm{Ta}_{2}$ ble 2) have been reported for U.S. cigarettes. In fact, we have ourselves observed a similar difference in reaction rates with a U.S. blended cigarette and with 2 French (dark tobacco) type cigarette.

Our observations imply a catalytic oxidation process which does not occur in the presence of particulates and in the following footnote* we offer a possible explanation.

Peroxy radicals are known to react rapidly with nitric oxide,

$$
\mathrm{ROO}+\mathrm{NO} \longrightarrow \mathrm{RO} \cdot+\mathrm{NO}_{2},
$$

and clearly such reaction schemes in which the free radicals are not consumed can explain the first order oxidation of nitric oxide observed in the gas phase in this work, since the kinetics of the reaction with the hydroperoxy radical for example are believed to be second order (11). However, we have observed rapid oxidation over a period of 10 minutes which is much longer than the time scale expected for the removal of the free radicals involved. This can be reconciled if it is remembered that the removal reactions of these radicals can generate molecules such as peroxy nitrates which decompose slowly at room temperature to yield free radicals which can oxidise nitric oxide (Fig. 5). If, as our results suggest, the particulate material impedes rapid oxidation of the nitric oxide by free radicals then the measurements made of the latter species in the gas phase in isolation (10) may be erroneously high when considering the smoke as a whole. Electron spin resonance studies give the gas phase concentration of oxygen-centred free radicals as $5 \times 10^{14}$ spins per $35 \mathrm{ml}$ puff $=2.3 \times 10^{-11} \mathrm{~mol} \mathrm{~cm}^{-3}(10)$. Using the second order rate constant of $6.5 \times 10^{12} \mathrm{~cm}^{3} \mathrm{~mol}^{-1} \mathrm{~s}^{-1}$ (11) for the reaction of nitric oxide with a hydroperoxy radical gives a first order rate constant for nitric oxide disappearance of $1.5 \times 10^{2} \mathrm{~s}^{-1}$. This figure is rather greater than we have determined experimentally and may suggest that another reaction in the sequence is rate limiting. We accept, however, that further studies are required before the kinetics of the gas phase reaction can be conclusively characterised. It would, for example, increase the precision of the rate constants obtained if the change in nitric oxide concentration could be monitored continuously, rather than on an intermittent basis. However, the implication from our data that particulate matter "quenches" highly active oxygen-containing species is significant. Since these latter species are alleged to be toxic, experiments in which animals, enzymes and cell suspensions are exposed to isolated gas phase may yield results not applicable to whole smoke.

\footnotetext{
* The fact that oxidation in the gas phase is more rapid than oxidation by oxygen requires the presence of highly reactive oxidant species. Oxygen-containing free radicals are known to be present in cigarette smoke $(10)$ and could recombine on the surface of smoke particles, explaining the slower disappearance in the whole smoke.
}

Similarly, unless conditions exist in the respiratory tract where separation of gas phase and particulates occurs, oxygen-centred free radicals may not reach levels sufficient to cause toxicity.

\section{Figure 5.}

Possible reaction mechanisms in the NO ageing process ( $R$ represents an alkyl group).
1. NO
+ HOO. HO- $+\mathrm{NO}_{2}$
2. HO.
$+\mathrm{RCH}_{3}$ $\mathrm{RCH}_{2}$ $+\mathrm{H}_{2} \mathrm{O}$
3. $\mathrm{RCH}_{2} \cdot+\mathrm{O}_{2}$ $\mathrm{RCH}_{2} \mathrm{OO}$.
4. $\mathrm{RCH}_{2} \mathrm{OO}+\mathrm{NO}$ $\longrightarrow \mathrm{RCH}_{2} \mathrm{O}+\mathrm{NO}_{2}$
$\mathrm{RCHO}+\mathrm{HOO}$
5. $\mathrm{RCH}_{2} \mathrm{O} \cdot+\mathrm{O}_{2}$

\section{REFERENCES}

1. Norman, V., and C. H. Keith: Nitrogen oxides in tobacco smoke; Nature (Lond.) 205 (1965) 915916.

2. Sloan, C. H., and J. E. Kiefer: Determination of $\mathrm{NO}$ and $\mathrm{NO}_{2}$ in cigarette smoke from kinetic data; Tob. Sci. 13 (1969) 180-182.

3. Neurath, G. B., M. Dünger and F. G. Pein: Interaction of nitrogen oxides, oxygen and amines in gaseous mixtures; in: Environmental $N$-nitroso compounds analysis and formation, edited by $\mathrm{E}$. $\mathrm{A}$. Walker, P. Bogovski, L. Griciute and W. Davis, IARC Scientific Publication No. 14, International Agency for Research on Cancer, Lyon, 1976, Pp. 215-225.

4. Barkemeyer, H., and F. Seehofer: Zur Untersuchung der Gas-Dampf-Phase des Cigarettenrauches, 2. Mitteilung: Zur Bestimmung des Stickstoffmonoxids (NO) aus der Gasphase des Cigarettenrauches; Beitr. Tabakforsch. 4 (1968) 278-282.

5. Vilcins, G., and J. O. Lephardt: Ageing processes of cigarette smoke / Formation of methyl nitrite; Chem. Ind. (Lond.) 1975, 974-975.

6. Baulch, D. L., D. D. Drysdale, D. G. Horne and A. C. Lloyd: Evaluated kinetic data for high-temperature reactions, Vol. 1: Homogeneous gas-phase reactions of the $\mathrm{H}_{2}-\mathrm{O}_{2}$ system; Butterworths, London, 1972.

7. Williams, T. B.: The determination of nitric oxide in gas phase cigarette smoke by non-dispersive infrared analysis; Beitr. Tabakforsch. Int. 10 (1980) 91-99.

8. Rothwell, K., and C. A. Grant: Standard methods for the analysis of tobacco smoke; TRC Research Paper No. 11, 2nd edition, Tobacco Research Council, London, 1974. 
9. Clyne, M. A. A., B. A. Thrush and R: P. Wayne: Kinetics of chemiluminescent reaction between nitric oxide and ozone; Trans. Faraday Soc. 60 (1964) $359-367$.

10. Prior, W. A., D. G. Prier and D. F. Church: Electron-spin resonance study of mainstream and sidestream cigarette smoke / Nature of the free radicals in gas-phase smoke and in cigarette tar; Environ. Health Perspect. 47 (1983) 345-355.

11. Cox, R. A., and G. S. Tyndall: Rate constants for the reactions of $\mathrm{CH}_{3} \mathrm{O}_{2}$ with $\mathrm{HO}_{2}, \mathrm{NO}$ and $\mathrm{NO}_{2}$ using molecular modulation spectroscopy; J. Chem. Soc. Faraday Trans. II 76 (1980) 153-163.
Addresses of authors:

Dr. C. D. R. Borland and Dr. T. W. Higenbottam, Department of Respiratory Pbysiology,

Addenbrooke's Hospital,

Cambridge, CB2 2QQ England.

Dr. B. A. Thrush,

Department of Physical Chemistry,

Chemical Laboratory,

University of Cambridge,

Lensfield Road,

Cambridge, England. 